\title{
Pengaruh Suhu dan Lama Pelayuan Terhadap Karakteristik Teh Herbal Daun Kenikir (Cosmos caudatus Kunth.)
}

\author{
The Effect of Temperature and Duration of Withering on The Characteristics of Herbal Tea of \\ Kenikir Leaves (Cosmos caudatus Kunth.)
}

\author{
Maria Aprilia*. Ni Wayan Wisaniyasa, I Ketut Suter \\ Program Studi Ilmu dan Teknologi Pangan, Fakultas Teknologi Pertanian, \\ Universitas Udayana, Jl. Raya Kampus Unud, Jimbaran, Kuta Selatan, Badung-Bali \\ *Penulis korespondensi: Maria Aprilia, Email: Maria.aprilia97@gmail.com
}

\begin{abstract}
This research aimed was to determine the effect of temperature and duration of withering on the characteristics of herbal tea of kenikir leaves (Cosmos caudatus Kunth.) and to know the right temperature and duration of withering time to get the best characteristics of herbal tea. The experimental design used was Completely Randomized Design with two factors which were withering temperature $\left(70^{\circ} \mathrm{C}, 80^{\circ} \mathrm{C}\right.$, and $\left.90^{\circ} \mathrm{C}\right)$ and withering duration $(1,2$, and 3 minutes). All of the treatment was repeated two times to obtain 18 units of experiments. The data obtained were analyzed by variance and if the treatment had a significant effect followed by The Duncan Multiple Range Test. The results showed that interaction of temperature and withering time had a very significant effect on moisture content, total phenolics, total flavonoids, antioxidant activity, and color (scoring test). The results showed that interaction $90^{\circ} \mathrm{C}$ of withering temperature during 2 minutes was the best treatment to produce kenikir leaves herbal tea with the moisture content $6,76 \% \mathrm{~b} / \mathrm{b}$, extract content $32,89 \%$, vitamin C 3,35 mg /g total phenolics 79,26 mg GAE/g, total flavonoids $161,01 \mathrm{mg}$ QE/g and antioxidant activity 74,29\% with $\mathrm{IC}_{50}$ valued $24,409 \mathrm{ppm}$. The brew of kenikir leaves herbal tea had a rather typical aroma of kenikir leaf and liked, yellow greenness color and liked, rather bitter taste and usual as well as with overall acceptance.
\end{abstract}

Keywords : Characteristics of herbal tea, kenikir leaves, withering temperature, withering duration

\section{PENDAHULUAN}

Tanaman kenikir merupakan tanaman daerah tropis yang berasal dari Amerika Latin yang dapat mudah tumbuh di berbagai tempat. Daun kenikir (Cosmos caudatus Kunth.) mengandung senyawa alkaloid, saponin, steroid, fenol, terpenoid, dan flavonoid (Batari, 2007). Saat ini banyak penelitian yang menunjukan bahwa daun kenikir dapat bermanfaat dalam mencegah dan mengobati penyakit. Menurut Bunawan et al. (2014), daun kenikir memiliki manfaat sebagai antibakteri, antifungi, antiosteoporosis, antioksidan, antidiabetes dan antihipertensi.
Di Indonesia, pemanfaatan daun kenikir kurang maksimal karena hanya digunakan sebagai sayuran pelengkap makanan seperti lalapan, pecel dan urap. Salah satu cara untuk meningkatkan pemanfaatan daun kenikir yaitu diolah menjadi teh herbal. Teh herbal merupakan istilah umum yang digunakan untuk minuman berbahan baku tanaman seperti akar, bunga, batang dan daun yang bukan berasal dari tanaman teh Camellia sinensis (Yudana, 2004). Penelitian sebelumnya oleh Fatanah et al. (2016) tentang teh herbal daun kenikir berdasarkan tingkat ketuaan daun kenikir. Hasil penelitian tersebut menunjukan bahwa teh herbal daun kenikir yang menggunakan daun 
muda mempunyai kandungan bioaktif dan aktivitas antioksidan yang paling tinggi dibandingkan daun dewasa dan daun tua. Namun, pada penelitian tersebut tidak ada perlakuan pendahuluan berupa pelayuan pada daun kenikir.

Pelayuan merupakan salah satu proses yang berpengaruh dalam menentukan produk teh dari segi warna, aroma dan rasa. Pada pengolahan teh hijau, pelayuan bertujuan untuk menginaktifkan enzim polifenol oksidase sehingga mengurangi terjadinya oksidasi senyawa antioksidan (Yulianto et al., 2006) dan juga mencegah terjadinya proses fermentasi pada daun teh. Proses pelayuan pada pengolahan teh hijau memiliki dua metode yaitu metode penyangraian dan metode steaming. Metode steaming pada umumnya menggunakan suhu $70-100^{\circ} \mathrm{C}$, sedangkan metode penyangraian menggunakan suhu sekitar $180^{\circ} \mathrm{C}$. Secara umum, enzim polifenol oksidase akan inaktif pada suhu $70-90^{\circ} \mathrm{C}$, tetapi waktu yang dibutuhkan untuk menginaktivasi tergantung sifat produk (Queiroz et al., 2008).

Felicia et al. (2016) melaporkan bahwa metode steaming dalam pengolahan teh daun alpukat menghasilkan total fenol, total flavonoid dan aktivitas antioksidan yang lebih tinggi dibandingkan dengan metode penyangraian. Selain itu, metode steaming pada teh daun alpukat menghasilkan warna hijau kekuningan pada seduhan teh. Selanjutnya, Yulianto et al. (2006) melaporkan proses pelayuan pada daun teh menggunakan metode steaming dengan suhu $80^{\circ} \mathrm{C}$ sudah menunjukkan penurunan aktivitas enzim dan suhu $90^{\circ} \mathrm{C}$ membuat penurunan aktivitas enzim semakin drastis. Menurut penelitian
Nurhayati et al. (2018), steaming pada biji kakao selama 1 dan 3 menit dapat menurunkan aktivitas enzim polifenol oksidase sebanyak 93 - 97\%, meningkatkan kandungan total polifenol dan aktivitas antioksidan. Adri dan Wikanastri (2013) melaporkan bahwa pelayuan daun sirsak pada suhu $70^{\circ} \mathrm{C}$ selama 4 menit menghasilkan aktivitas antioksidan tertinggi yaitu sebesar $76,06 \%$. Oleh karena itu, diperlukan penelitian tentang pengaruh suhu dan lama pelayuan yang tepat dalam pembuatan teh herbal daun kenikir untuk menghasilkan teh herbal daun kenikir dengan karakteristik terbaik.

\section{METODE PENELITIAN}

\section{Tempat dan Waktu}

Pengolahan teh herbal daun kenikir dilaksanakan di Laboratorium Pengolahan Pangan Fakultas Teknologi Pertanian Universitas Udayana. Proses analisis dilaksanakan di Laboratorium Analisis Pangan, Laboratorium Mikrobiologi Pangan, Laboratorium Rekayasa dan Pengendalian Mutu Fakultas Teknologi Pertanian, Universitas Udayana. Penelitian ini dilaksanakan pada bulan April sampai dengan bulan Juli 2019.

\section{Bahan dan Alat}

Bahan baku yang digunakan adalah daun kenikir muda dan segar dengan kriteria berwarna hijau dan diambil dari satu sampai empat tingkatan di bawah pucuk yang diperoleh dari perkebunan Jalan Raya Puputan, Denpasar. Bahan kimia yang digunakan antara lain : aquadest, standar kuersetin, standar asam askorbat, metanol, 2,2-diphenyl-1-picrylhydrazyl (DPPH), reagen 
Folin-Ciocalteu, $\mathrm{Na}_{2} \mathrm{CO}_{3}, \mathrm{NaNO}_{2}, \mathrm{NaOH}, \mathrm{AlCl}_{3}$, asam galat, aluminium foil, dan kertas saring Whatman no 1.

Alat yang digunakan dalam penelitian ini yaitu oven, kompor, kuas, ayakan ukuran 40 mesh, muffle, cawan oven, spektrofotometer (Genesys 10S UV-Vis), desikator, timbangan analitik (Shimadzu ATY224), pinset, vortex, dandang ukuran $30 \mathrm{~cm}$, stopwatch, thermometer, blender, loyang oven, botol gelap, rak tabung, pipet volume, pipet mikro, pipet tetes, waterbath, spatula, pipet filler dan alat-alat gelas.

\section{Rancangan Percobaan}

Penelitian ini menggunakan Rancangan Acak Lengkap (RAL) pola faktorial yang terdiri dari dua faktor yaitu suhu dan lama pelayuan. Faktor pertama yaitu suhu pelayuan dengan tiga taraf perlakuan sebagai berikut :
a. $\mathrm{S}_{1}=70^{\circ} \mathrm{C}$
b. $\mathrm{S}_{2}=80^{\circ} \mathrm{C}$
c. $\mathrm{S}_{3}=90^{\circ} \mathrm{C}$

Faktor kedua yaitu lama pelayuan dengan tiga taraf perlakuan sebagai berikut :
a. $\mathrm{t}_{1}=1$ menit
b. $t_{2}=2$ menit
c. $\mathrm{t}_{3}=3$ menit

Perlakuan di atas dikombinasikan menjadi $\left(S_{1} t_{1}\right),\left(S_{1} t_{2}\right),\left(S_{1} t_{3}\right),\left(S_{2} t_{1}\right),\left(S_{2} t_{2}\right),\left(S_{2} t_{3}\right)\left(S_{3} t_{1}\right),\left(S_{3} t_{2}\right)$, $\left(\mathrm{S}_{3} \mathrm{t}_{3}\right)$ dan diulang sebanyak 2 kali sehingga diperoleh 18 unit percobaan. Data yang diperoleh dianalisis menggunakan sidik ragam dan apabila perlakuan berpengaruh terhadap variabel maka dilanjutkan dengan uji Duncan's Multiple Range (DMRT) (Gomes dan Gomes, 1995).

\section{Pelaksanaan Penelitian}

\section{Pembuatan Teh Herbal Duun Kenikir}

Penelitian ini diawali dengan melakukan pemetikan daun kenikir yang muda dan segar yaitu satu hingga empat tingkatan di bawah pucuk daun dan diperoleh di perkebunan Jalan Raya Puputan, Denpasar, lalu dilakukan sortasi daun kenikir meliputi kesegaran daun, keutuhan daun, dan tidak terdapat bercak-bercak. Selanjutnya, dilakukan trimming untuk memisahkan daun kenikir dengan tangkainya. Daun yang sudah dipisahkan dengan tangkainya, kemudian dicuci dengan air mengalir dan daun ditiriskan.

Proses selanjutnya yaitu proses pelayuan dengan menggunakan metode steaming dengan suhu $70^{\circ} \mathrm{C}, 80^{\circ} \mathrm{C}$ dan $90^{\circ} \mathrm{C}$ selama 1,2 dan 3 menit, selanjutnya dilakukan pendinginan selama 5 menit. Proses selanjutnya yaitu pengeringan menggunakan oven dengan suhu $60^{\circ} \mathrm{C}$ selama 3,5 jam, lalu dilakukan penggilingan bertujuan untuk menghaluskan daun yang dilakukan dengan menggunakan blender, lalu dilakukan pengayakan dengan ayakan berukuran 40 mesh. Bubuk teh herbal daun kenikir kemudian di analisis secara kimia dan sisanya dikemas ke dalam kantong teh celup. Masing- masing kantong teh celup berisi 2 gram serbuk teh herbal daun kenikir. Selanjutnya, dianalisis secara sensoris.

\section{Proses Pembuatan Filtrat Teh Herbal Daun Kenikir}

Bubuk teh daun kenikir sebanyak 1 gram dilarutkan dengan $50 \mathrm{ml}$ metanol 80\%, kemudian di-shaker dengan menggunakan rotary shaker selama 1 jam pada suhu ruang. Selanjutnya, sampel disaring dengan menggunakan kertas 
saring Whatman no 1. Filtrat yang dihasilkan dimasukan ke dalam botol dan disimpan di dalam freezer sampai dianalisis total fenol, total flavonoid, kadar vitamin $\mathrm{C}$ dan aktivitas antioksidan (Ghasemzadeh et al., 2012).

\section{Pembuatan Seduhan Teh untuk Uji Sensoris}

Satu kantong teh herbal daun kenikir celup sebanyak 2 gram dimasukkan ke dalam gelas, kemudian ditambahkan air mendidih sebanyak $200 \mathrm{ml}$ dan diseduh selama 3 menit. Dalam waktu 3 menit, kantong teh celup digerakkan naik turun dalam air. Setelah itu, kantong teh celup dikeluarkan dari larutan dan larutan dibiarkan sampai suhu kamar. Larutan diuji secara organoleptik (Horzic et al., 2009).

\section{Parameter yang diamati}

Parameter yang diamati dalam penelitian ini adalah kadar air (AOAC, 2005), kadar ekstrak dalam air (SNI 01-3836-2000), total fenol (Garcia et al., 2007), total flavonoid (Josipovic et al., 2016), aktivitas antioksidan (Shah dan Modi, 2015), serta karakteristik

sensoris yang meliputi: warna, rasa, aroma, dan penerimaan keseluruhan terhadap seduhan teh herbal daun kenikir (Soekarto, 1990).

\section{HASIL DAN PEMBAHASAN}

\section{Kadar Air}

Analisis kadar air bubuk teh herbal daun kenikir dapat dilihat pada Tabel 1. Hasil sidik ragam menunjukan bahwa interaksi antara suhu dan lama pelayuan daun kenikir berpengaruh sangat nyata $(P<0,01)$ terhadap kadar air bubuk teh herbal daun kenikir. Berdasarkan Tabel 1, kadar air terendah diperoleh pada suhu pelayuan $90^{\circ} \mathrm{C}$ selama 3 menit yaitu sebesar $6,49 \%$ dan kadar air tertinggi diperoleh pada perlakuan suhu pelayuan $70^{\circ} \mathrm{C}$ selama 1 menit yaitu sebesar $7,56 \%$. Semakin tinggi suhu dan semakin lama pelayuan, maka kadar air akan semakin kecil. Hal ini disebabkan oleh semakin tinggi suhu pelayuan dan semakin lama pelayuan, maka semakin besar energi panas yang dibawa udara, sehingga jumlah massa cairan yang diuapkan dari bahan semakin banyak. Energi panas yang diterima akan mengubah kandungan air di dalam bahan menjadi uap, sehingga uap air akan berpindah ke permukaan bahan dan kemudian dilepaskan ke lingkungan bahan (Holman, 1995).

Menurut Suksmadji (1987), adanya pemanasan pada bahan pangan akan menyebabkan dinding sel menjadi lunak dan permeabel terhadap air. Umumnya perlakuan panas yang berlebihan akan merusak sifat osmotik dinding sel dan turgor sel yang dapat menurunkan elastisitas dinding sel, sehingga banyaknya air yang berikatan dengan jaringan akan lebih mudah teruapkan dengan menurunnya elastisitas dinding sel. (Neuma, 1972). Kadar air yang didapatkan dalam penelitian ini telah memenuhi standar SNI 4324 : 2014 tentang teh hijau celup yaitu memiliki standar kadar air sebesar maksimal 10\%.

\section{Kadar Ekstrak dalam Air}

Analisis kadar ekstrak dalam air bubuk teh herbal daun kenikir dapat dilihat pada Tabel 2 . Hasil sidik ragam menunjukkan bahwa interaksi antara suhu dan lama pelayuan berpengaruh tidak nyata $(P>0,05)$ terhadap kadar ekstrak dalam air teh herbal daun kenikir, sedangkan masing- 
masing perlakuan suhu pelayuan dan lama pelayuan berpengaruh sangat nyata $(P<0,01)$ terhadap kadar ekstrak dalam air.

Kadar ekstrak dalam air terendah diperoleh dari perlakuan suhu pelayuan $70^{\circ} \mathrm{C}$ yaitu sebesar $30,18 \%$ yang berbeda tidak nyata dengan suhu pelayuan $80 \mathrm{C}$ dan kadar ekstrak dalam air tertinggi diperoleh dari pelakuan suhu pelayuan $90^{\circ} \mathrm{C}$ yaitu sebesar $32,56 \%$. Kadar ekstrak dalam air yang diperoleh dari perlakuan suhu pelayuan $90^{\circ} \mathrm{C}$ sesuai dengan standar SNI 4324: 2014 tentang teh hijau celup yaitu minimal $32 \%$.
Kadar ekstrak dalam air terendah diperoleh dari perlakuan lama pelayuan 1 menit yaitu sebesar 30,30\% dan kadar ekstrak dalam air tertinggi diperoleh dari perlakuan lama pelayuan 3 menit yaitu sebesar $31,89 \%$ yang berbeda tidak nyata dengan lama pelayuan 2 menit. Hal ini disebabkan karena lamanya pelayuan dapat membuat air di dalam bahan banyak diuapkan, sehingga kadar ekstrak dalam air akan semakin besar.

Tabel 1. Nilai rata-rata kadar air bubuk teh herbal daun kenikir (\%)

\begin{tabular}{cccc}
\hline \multirow{2}{*}{ Suhu Pelayuan } & \multicolumn{3}{c}{ Lama Pelayuan } \\
\cline { 2 - 4 } & 1 menit & 2 menit & 3 menit \\
\hline $70^{\circ} \mathrm{C}$ & $7,56 \pm 0,07 \mathrm{~b}$ & $7,36 \pm 0,06 \mathrm{ab}$ & $7,20 \pm 0,09 \mathrm{a}$ \\
& $\mathrm{B}$ & $\mathrm{B}$ & $\mathrm{B}$ \\
$80^{\circ} \mathrm{C}$ & $7,33 \pm 0,02 \mathrm{~b}$ & $7,29 \pm 0,07 \mathrm{~b}$ & $7,06 \pm 0,05 \mathrm{a}$ \\
& $\mathrm{A}$ & $\mathrm{B}$ & $\mathrm{B}$ \\
$90^{\circ} \mathrm{C}$ & $7,23 \pm 0,04 \mathrm{c}$ & $6,76 \pm 0,06 \mathrm{~b}$ & $6,49 \pm 0,07 \mathrm{a}$ \\
& $\mathrm{A}$ & $\mathrm{A}$ & $\mathrm{A}$ \\
\hline
\end{tabular}

Keterangan : Huruf yang sama pada baris atau kolom yang sama menunjukan perlakuan tidak berbeda nyata $(P>0,05)$. Notasi huruf dibelakang nilai rata-rata dilihat per baris, sedangkan notasi huruf di bawah nilai rata-rata dilihat per kolom.

Tabel 2. Nilai rata-rata kadar ekstrak dalam air bubuk teh herbal daun kenikir pada suhu yang berbeda (\%)

\begin{tabular}{ccccc}
\hline \multirow{2}{*}{ Suhu Pelayuan } & \multicolumn{4}{c}{ Lama Pelayuan } \\
\cline { 2 - 5 } & 1 menit & 2 menit & 3 menit & $\bar{X}($ suhu $)$ \\
\hline $70^{\circ} \mathrm{C}$ & $29.57 \pm 0,50$ & $30.47 \pm 0,60$ & $30.51 \pm 0,49$ & $30,18 \pm 0,53 \mathrm{a}$ \\
$80^{\circ} \mathrm{C}$ & $29.93 \pm 0,46$ & $30.57 \pm 0,39$ & $31.79 \pm 0,67$ & $30,76 \pm 0,94 \mathrm{a}$ \\
$90^{\circ} \mathrm{C}$ & $31.40 \pm 0,81$ & $32.89 \pm 0,38$ & $33.39 \pm 0,28$ & $32,56 \pm 1,04 \mathrm{~b}$ \\
$\bar{X}$ (lama) & $30,30 \pm 0,97 \mathrm{a}$ & $31,31 \pm 1,37 \mathrm{~b}$ & $31,89 \pm 1,44 \mathrm{~b}$ & \\
\hline
\end{tabular}

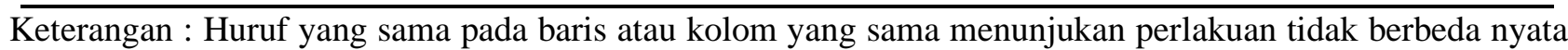
$(P>0,05)$. 


\section{Total Vitamin C}

Analisis kadar vitamin $\mathrm{C}$ bubuk teh herbal daun kenikir dapat dilihat pada Tabel 3. Hasil sidik ragam menunjukkan bahwa interaksi antara suhu dan lama pelayuan berpengaruh tidak nyata $(P>0,05)$ terhadap total vitamin $\mathrm{C}$ teh herbal daun kenikir, namun masing-masing perlakuan suhu pelayuan dan lama pelayuan berpengaruh sangat nyata $(P<0,01)$ terhadap total vitamin $\mathrm{C}$.

Tabel 3 menunjukan bahwa kadar vitamin C terendah diperoleh dari perlakuan suhu pelayuan $90^{\circ} \mathrm{C}$ yaitu sebesar $3,42 \mathrm{mg} / \mathrm{g}$. Bubuk dan kadar vitamin $\mathrm{C}$ tertinggi diperoleh dari perlakuan suhu pelayuan $70^{\circ} \mathrm{C}$ yaitu sebesar 3,60 $\mathrm{mg} / \mathrm{g}$. Semakin tinggi suhu pelayuan, maka total vitamin $\mathrm{C}$ bubuk teh herbal daun kenikir akan semakin kecil. Hal ini disebabkan karena semakin tinggi suhu pelayuan membuat kandungan vitamin C mengalami degradasi oleh panas. Vitamin $\mathrm{C}$ mudah rusak apabila bersentuhan dengan udara (oksidasi), terutama terkena panas (Almatsier, 2004). Suhu yang tinggi yaitu $90^{\circ} \mathrm{C}$ bertanggung jawab atas degradasi vitamin $\mathrm{C}$ yang labil panas.
Menurut Uckiah et al. (2009), panas menyebabkan laju peningkatan reaksi kimia dan meningkatkan laju oksidasi vitamin $\mathrm{C}$, sehingga menyebabkan oksidasi asam askorbat lebih lanjut dan menjadikan senyawa vitamin $\mathrm{C}$ tidak memiliki keaktifan sebagai vitamin $\mathrm{C}$.

Tabel 3, kadar vitamin $\mathrm{C}$ terendah diperoleh dari perlakuan lama pelayuan 3 menit yaitu sebesar 3,37 mg/g bubuk dan kadar vitamin $\mathrm{C}$ tertinggi diperoleh dari perlakuan lama pelayuan 1 menit yaitu sebesar 3,64 mg/g bubuk. Hal ini menunjukan bahwa semakin lama pelayuan, maka kadar vitamin $\mathrm{C}$ bubuk teh herbal daun kenikir akan semakin kecil. Hal ini disebabkan karena lamanya pelayuan menyebabkan panas yang diberikan pada bahan akan semakin besar dan menyebabkan total vitamin $\mathrm{C}$ semakin menurun. Menurut Ramdani et al. (2018), semakin singkat waktu blansing yang digunakan, maka kandungan vitamin $\mathrm{C}$ semakin besar di dalam bahan pangan.

Tabel 3. Nilai rata-rata vitamin $\mathrm{C}$ bubuk teh herbal daun kenikir (mg/g)

\begin{tabular}{ccccc}
\hline \multirow{2}{*}{ Suhu Pelayuan } & \multicolumn{4}{c}{ Lama Pelayuan } \\
\cline { 2 - 5 } & 1 menit & 2 menit & 3 menit & $\bar{X}($ suhu $)$ \\
\hline $70^{\circ} \mathrm{C}$ & $3,73 \pm 0,05$ & $3,65 \pm 0,07$ & $3,41 \pm 0,03$ & $3,60 \pm 0,07 \mathrm{c}$ \\
$80^{\circ} \mathrm{C}$ & $3,61 \pm 0,08$ & $3,55 \pm 0,05$ & $3,38 \pm 0,08$ & $3,51 \pm 0,15 \mathrm{~b}$ \\
$90^{\circ} \mathrm{C}$ & $3,60 \pm 0,05$ & $3,35 \pm 0,06$ & $3,31 \pm 0,07$ & $3,42 \pm 0,05 \mathrm{a}$ \\
$\bar{X}$ (lama) & $3,64 \pm 0,02 \mathrm{c}$ & $3,52 \pm 0,01 \mathrm{~b}$ & $3,37 \pm 0,02 \mathrm{a}$ & \\
\hline
\end{tabular}

Keterangan : Huruf yang sama pada kolom atau baris menunjukan perlakuan tidak berbeda nyata $(P>0,05)$. 


\section{Total Fenol}

Hasil analisis rata-rata total fenol bubuk teh herbal daun kenikir dapat dilihat pada Tabel 4 . Hasil sidik ragam menunjukan bahwa interaksi antara suhu dan lama pelayuan memberikan pengaruh yang sangat nyata $(P<0,01)$ terhadap total fenol bubuk teh herbal daun kenikir. Hasil penelitian menunjukan bahwa total fenol bubuk teh herbal daun kenikir terendah diperoleh dari perlakuan suhu $70^{\circ} \mathrm{C}$ selama 1 menit yaitu sebesar 47,25 mg GAE/g bubuk dan total fenol bubuk teh herbal daun kenikir tertinggi diperoleh dari perlakuan suhu $90^{\circ} \mathrm{C}$ selama 2 menit yaitu sebesar 79,26 mg GAE/g bubuk. Berdasarkan Tabel 4 secara umum terlihat bahwa pada suhu $70^{\circ} \mathrm{C}$ hingga $80^{\circ} \mathrm{C}$ dengan lama waktu 1-3 menit dan suhu $90^{\circ} \mathrm{C}$ selama 1-2 menit, total fenol mengalami peningkatan. Hal ini disebabkan karena pada suhu dan lama pelayuan tersebut menyebabkan enzim polifenol oksidasi terdenaturasi. Enzim akan terdenaturasi apabila mendapat perlakuan di atas suhu optimumnya.
Menurut Ratnaningrum et al., (2018) bahwa pelayuan dengan suhu tinggi akan menyebabkan bagian protein dari enzim mulai terdenaturasi sehingga enzim menjadi inaktif. Menurut Mardiah (2011), di dalam bahan pangan terdapat enzim polifenol oksidase yang dapat mengkatalisis proses oksidasi fenol menjadi senyawa kuinon. Perubahan suhu akan mempengaruhi aktivitas dan stabilitas enzim tersebut. Namun, pada suhu pelayuan $90^{\circ} \mathrm{C}$ dengan lama pelayuan 3 menit, maka terjadi penurunan total fenol menjadi $65,31 \mathrm{mg} \mathrm{GAE} / \mathrm{g}$ bubuk. Hal ini disebabkan karena kandungan fenol di dalam daun kenikir menjadi rusak pada suhu tinggi dengan waktu yang lebih lama. Menurut Yulianto et al. (2006), kenaikan suhu lebih lanjut akan menyebabkan uap panas menembus dinding tonoplas, akibatnya katekin yang berada di dalam vakuola akan berpenetrasi dengan uap panas, sehingga mengalami degradasi pada suhu yang tinggi dan waktu yang lama.

Tabel 4. Nilai rata-rata total fenol bubuk teh herbal daun kenikir (mg GAE/g bubuk)

\begin{tabular}{cccc}
\hline \multirow{2}{*}{ Suhu Pelayuan } & \multicolumn{3}{c}{ Lama Pelayuan } \\
\cline { 2 - 4 } & 1 menit & 2 menit & 3 menit \\
\hline $70^{\circ} \mathrm{C}$ & $47,25 \pm 0,97 \mathrm{a}$ & $55,81 \pm 0,96 \mathrm{~b}$ & $66,99 \pm 0,60 \mathrm{c}$ \\
& $\mathrm{B}$ & $\mathrm{A}$ & $\mathrm{A}$ \\
$80^{\circ} \mathrm{C}$ & $63,86 \pm 0,79 \mathrm{a}$ & $71,33 \pm 0,55 \mathrm{~b}$ & $74,75 \pm 0,85 \mathrm{c}$ \\
& $\mathrm{B}$ & $79,26 \pm 0,52 \mathrm{c}$ & $\mathrm{B}$ \\
$90^{\circ} \mathrm{C}$ & $74,37 \pm 0,80 \mathrm{~b}$ & $\mathrm{C}$ & $65,31 \pm 0,53 \mathrm{a}$ \\
& $\mathrm{C}$ & $\mathrm{C}$ & $\mathrm{A}$
\end{tabular}

Keterangan : Huruf yang sama pada kolom atau baris menunjukan perlakuan tidak berbeda nyata $(P>0,05)$. Notasi huruf dibelakang nilai rata-rata dilihat per baris, sedangkan notasi huruf di bawah nilai rata-rata dilihat per kolom. 


\section{Total Flavonoid}

Hasil analisis rata-rata total fenol bubuk teh herbal daun kenikir dapat dilihat pada Tabel 5. Hasil sidik ragam menunjukan bahwa interaksi antara suhu dan lama pelayuan memberikan pengaruh yang sangat nyata $(P<0,01)$ terhadap total flavonoid bubuk teh herbal daun kenikir. Hasil penelitian menunjukkan bahwa total flavonoid bubuk teh herbal daun kenikir terendah diperoleh dari perlakuan suhu $70^{\circ} \mathrm{C}$ selama 1 menit yaitu sebesar 100,22 mg QE/g bubuk teh herbal daun kenikir dan total flavonoid bubuk teh herbal daun kenikir tertinggi diperoleh dari perlakuan suhu $90^{\circ} \mathrm{C}$ selama 2 menit yaitu sebesar 161,01 mg QE/g bubuk teh herbal daun kenikir yang tidak berbeda nyata dengan suhu pelayuan $80^{\circ} \mathrm{C}$ selama 3 menit.

Berdasarkan Tabel 5, pada suhu $70^{\circ} \mathrm{C}$ hingga $80^{\circ} \mathrm{C}$ dengan lama waktu $1-3$ menit, total flavonoid mengalami peningkatan. Hal ini dapat disebabkan karena pemanasan dapat merusak jaringan matriks yang membantu pengikatan total fenolik dengan pektin atau jaringan selulosa, sehingga senyawa fenolik dapat lebih mudah terekstrak dengan pelarut yang digunakan (Saikia dan Charu, 2013).

Namun, pada suhu pelayuan $90^{\circ} \mathrm{C}$ selama 3 menit terjadi penurunan total flavonoid menjadi 134,33 $\mathrm{mg}$ QE/g bubuk atau mengalami penurunan sebesar $11,71 \%$. Hal ini disebabkan oleh penurunan total. Hal ini disebabkan karena flavonoid merupakan senyawa fenolik terbesar di dalam tumbuhan, sehingga menurunnya total fenol diikuti juga dengan menurunnya total flavonoid.

\section{Aktivitas Antioksidan}

Hasil analisis aktivitas antioksidan bubuk teh herbal daun kenikir dapat dilihat pada Tabel 6 . Hasil sidik ragam menunjukan bahwa interaksi antara suhu dan lama pelayuan daun kenikir berpengaruh sangat nyata $(P<0,01)$ terhadap aktivitas antioksidan bubuk teh herbal daun kenikir. Hasil penelitian menunjukan bahwa aktivitas antioksidan terendah diperoleh dari perlakuan suhu pelayuan $70^{\circ} \mathrm{C}$ selama 1 menit yaitu sebesar 45,73\% dan aktivitas antioksidan tertinggi diperoleh dari perlakuan suhu pelayuan $90^{\circ} \mathrm{C}$ selama 2 menit yaitu sebesar $74,29 \%$.

Tabel 5. Nilai rata-rata uji total flavonoid bubuk teh daun kenikir (mg QE/g bubuk)

\begin{tabular}{cccc}
\hline \multirow{2}{*}{ Suhu Pelayuan } & \multicolumn{3}{c}{ Lama Pelayuan } \\
\cline { 2 - 4 } & $100,22 \pm 1,28 \mathrm{a}$ & 2 menit & 3 menit \\
\hline $70^{\circ} \mathrm{C}$ & $\mathrm{A}$ & $116,47 \pm 1,27 \mathrm{~b}$ & $\frac{\mathrm{A}}{\mathrm{B}}$ \\
$80^{\circ} \mathrm{C}$ & $127,83 \pm 1,25 \mathrm{a}$ & $137,50 \pm 1,26 \mathrm{~b}$ & $\mathrm{~B}$ \\
& $\mathrm{~B}$ & $161,01 \pm 1,34 \mathrm{c}$ & $152,15 \pm 1,28 \mathrm{c}$ \\
$90^{\circ} \mathrm{C}$ & $141,09 \pm 1,18 \mathrm{~b}$ & $\mathrm{C}$ & $134,33 \pm 1,22 \mathrm{a}$ \\
& $\mathrm{C}$ & $\mathrm{A}$ & \\
\hline
\end{tabular}

Keterangan : Huruf yang sama pada baris atau kolom yang sama menunjukan perlakuan tidak berbeda nyata $(P>0,05)$. Notasi huruf dibelakang nilai rata-rata dilihat per baris, sedangkan notasi huruf di bawah nilai rata-rata dilihat per kolom. 
Berdasarkan Tabel 6 pada suhu $70^{\circ} \mathrm{C}$ hingga $80^{\circ} \mathrm{C}$ dengan lama waktu 1-3 menit dan pada suhu $90^{\circ} \mathrm{C}$ selama 1-2 menit, aktivitas antioksidan mengalami peningkatan. Hal ini disebabkan karena total fenol dan total flavonoid pada suhu pelayuan dan lama pelayuan tersebut mengalami peningkatan. Kandungan fenol dan aktivitas antioksidan memiliki hubungan yang kuat dan merupakan faktor yang sangat signifikan dalam peningkatan dan penurunan aktivitas antioksidan (Volioglu et al., 1998). Menurut Prabandari (2015), terdapat korelasi positif antara aktivitas antioksidan dengan total fenol dan flavonoid, dimana semakin meningkatnya total fenol dan flavonoid, maka aktivitas antioksidan akan semakin meningkat juga.

Namun, pada suhu pelayuan $90^{\circ} \mathrm{C}$ dengan lama pelayuan 3 menit mengalami penurunan aktivitas antioksidan. Hal ini disebabkan karena pada suhu $90^{\circ} \mathrm{C}$ selama 3 menit terjadi penurunan.
Menurut Waji dan Andis (2009), senyawasenyawa yang mempunyai potensi sebagai antioksidan umumnya merupakan senyawa fenolik dan flavonoid. Perlakuan dengan aktivitas antioksidan tertinggi yaitu pada suhu pelayuan $90^{\circ} \mathrm{C}$ selama 2 menit dilakukan uji $\mathrm{IC}_{50}$ pada bubuk teh herbal daun kenikir. Nilai $\mathrm{IC}_{50}$ yang diperoleh yaitu sebesar 24,409 ppm. Menurut Molyneux (2004) Nilai IC $_{50}$ sebesar <50 ppm memiliki sifat antioksidan yang sangat kuat. Bubuk teh herbal daun kenikir memiliki nilai $\mathrm{IC}_{50}$ kurang dari $50 \mathrm{ppm}$ yang berarti bubuk teh herbal daun kenikir memiliki sifat antioksidan sangat kuat.

\section{Evaluasi Sensoris}

Evaluasi sensoris teh herbal daun kenikir dilakukan dengan uji skoring dan uji hedonik. Uji skoring dilakukan terhadap aroma, warna dan rasa. Uji hedonik dilakukan terhadap aroma, warna, rasa dan penerimaan keseluruhan.

Tabel 6. Nilai rata-rata aktivitas antioksidan bubuk teh herbal daun kenikir (\%)

\begin{tabular}{|c|c|c|c|}
\hline \multirow[b]{2}{*}{ Suhu Pelayuan } & \multicolumn{3}{|c|}{ Lama Pelayuan } \\
\hline & 1 menit & 2 menit & 3 menit \\
\hline $70^{\circ} \mathrm{C}$ & $45,73 \pm \frac{\mathrm{A}}{0,23 \mathrm{a}}$ & $55,88 \pm \frac{\mathrm{A}}{\mathrm{A}} 0,57 \mathrm{~b}$ & $68,04 \pm \frac{0,11 c}{A}$ \\
\hline $80^{\circ} \mathrm{C}$ & $60,86 \frac{ \pm}{B} 0,23 a$ & $62,34 \frac{ \pm}{B} 0,12 b$ & $69,00 \frac{ \pm}{B} 0,12 c$ \\
\hline $90^{\circ} \mathrm{C}$ & $71,93 \pm \frac{\mathrm{C}}{0,24 \mathrm{a}}$ & $74,29 \pm \frac{0}{\mathrm{C}}$ & $72,69 \pm \frac{0}{\mathrm{C}} 0,24 \mathrm{a}$ \\
\hline
\end{tabular}

Keterangan : Huruf yang sama pada kolom atau baris menunjukan perlakuan tidak berbeda nyata $(P>0,05)$. Notasi huruf dibelakang nilai rata-rata dilihat per baris, sedangkan notasi huruf di bawah nilai rata-rata dilihat per kolom.

\section{Aroma}

Hasil sidik ragam menunjukan bahwa perlakuan suhu dan lama pelayuan berpengaruh nyata $(P<0,05)$ terhadap aroma seduhan teh herbal daun kenikir yang dilakukan dengan uji skoring dan uji hedonik. Nilai rata-rata uji skoring 
dan uji hedonik aroma teh herbal daun kenikir dapat dilihat pada Tabel 7. Berdasarkan hasil uji skoring aroma teh herbal daun kenikir, panelis memberikan nilai rata-rata berkisar antara 3,2 3,8 dengan kriteria aroma agak khas daun kenikir sampai aroma khas daun kenikir. Semakin tinggi suhu pelayuan dan lama pelayuan daun kenikir, maka rata-rata nilai skoring semakin rendah. Hal ini dapat disebabkan oleh suhu yang tinggi dengan lamanya pelayuan akan menguapkan minyak atsiri di dalam daun kenikir, sehingga minyak atsiri di dalam daun kenikir akan semakin berkurang. Menurut Rachmani (2009), daun kenikir memiliki kandungan minyak atsiri sebesar $1,13 \% \mathrm{~b} / \mathrm{v}-$
$1,33 \% \mathrm{~b} / \mathrm{v}$. Hal ini didukung dengan penelitian Patin et al., 2018 yang menyatakan bahwa semakin tinggi suhu pengeringan, maka nilai skoring aroma teh daun sambiloto menurun. Berdasarkan hasil uji hedonik terhadap aroma seduhan teh, rata-rata panelis memberikan nilai 3,35 - 3,9 dengan kriteria biasa hingga suka. Hal ini menunjukkan bahwa aroma teh daun kenikir yang dihasilkan disukai oleh panelis. Menurut standar SNI 4345: 2014 tentang mutu teh hijau celup yaitu aroma teh hijau yang baik adalah normal yaitu aroma khas teh hijau dan aroma dari daun kenikir sudah sesuai persyaratan SNI teh hijau celup.

Tabel 7. Hasil uji skoring aroma teh herbal daun kenikir

\begin{tabular}{cccc}
\hline $\begin{array}{c}\text { Suhu } \\
\text { Pelayuan }\end{array}$ & Lama (menit) & Skoring & Hedonik \\
\hline \multirow{2}{*}{$\mathbf{7 0}^{\circ} \mathbf{C}$} & 1 & $3,80 \pm 0,83 \mathrm{c}$ & $3,90 \pm 0,50 \mathrm{~b}$ \\
& 2 & $3,70 \pm 0,80 \mathrm{c}$ & $3,60 \pm 0,67 \mathrm{ab}$ \\
& 3 & $3,60 \pm 0,50 \mathrm{c}$ & $3,55 \pm 0,83 \mathrm{ab}$ \\
$\mathbf{8 0}^{\circ} \mathbf{C}$ & 1 & $3,40 \pm 0,76 \mathrm{ab}$ & $3,75 \pm 0,76 \mathrm{ab}$ \\
& 2 & $3,45 \pm 0,82 \mathrm{ab}$ & $3,55 \pm 0,69 \mathrm{ab}$ \\
& 3 & $3,35 \pm 0,49 \mathrm{ab}$ & $3,50 \pm 0,76 \mathrm{ab}$ \\
$\mathbf{9 0}^{\circ} \mathbf{C}$ & 1 & $3,30 \pm 0,73 \mathrm{ab}$ & $3,55 \pm 0,51 \mathrm{ab}$ \\
& 2 & $3,25 \pm 0,79 \mathrm{a}$ & $3,55 \pm 0,55 \mathrm{ab}$ \\
& 3 & $3,20 \pm 0,77 \mathrm{a}$ & $3,35 \pm 0,64 \mathrm{a}$ \\
\hline
\end{tabular}

Keterangan : Huruf yang sama pada kolom yang sama menunjukan perlakuan tidak berbeda nyata $(P>0,05)$. Kriteria Nilai Skoring : 5 (Aroma sangat khas daun kenikir); 4 (aroma khas daun kenikir); 3 (aroma agak khas daun kenikir); 2 (aroma tidak khas daun kenikir); 1(aroma sangat tidak khas daun kenikir).

Kriteria Nilai Hedonik : 5 (Sangat suka); 4 (Suka); 3 (Biasa) ; 2 (Tidak suka); 1(Sangat tidak suka)

\section{Warna}

Hasil analisis uji skoring terhadap warna seduhan teh herbal daun kenikir yang dapat dilihat pada Tabel 8. Hasil sidik ragam menunjukan bahwa perlakuan suhu dan lama pelayuan berpengaruh sangat nyata $(P<0,01)$ terhadap warna air seduhan teh herbal daun kenikir yang diuji secara skoring. Nilai rata-rata uji skoring terhadap warna air seduhan teh herbal daun kenikir berkisar antara 2,25 - 4,25 dengan kriteria 
warna seduhan adalah kuning kemerahan hingga kuning kehijauan. Semakin tinggi suhu pelayuan dan semakin lama pelayuan daun kenikir, maka warna seduhan teh herbal daun kenikir berkriteria kuning kehijauan. Hal ini dapat disebabkan karena suhu pelayuan yang tinggi pada waktu yang optimal dapat menurunkan aktivitas enzim polifenol oksidase yang bekerja sebagai katalisator dalam proses oksidasi. Selain itu, proses steaming juga dapat menginaktifkan enzim chlorophyllase, dimana enzim tersebut dapat mengaktifkan proses degradasi klorofil menjadi feofitin dan feoforbid yang dapat mengubah warna kuning menjadi gelap apabila mendapatkan suhu yang tinggi (Chaturvedula dan Prakash, 2011). Hasil sidik ragam menunjukan bahwa perlakuan suhu dan lama pelayuan berpengaruh nyata $(P<0,05)$ terhadap warna seduhan teh herbal daun kenikir yang dilakukan uji secara hedonik. Hasil uji hedonik terhadap warna teh herbal daun kenikir dapat dilihat pada Tabel 8. Rata-rata panelis memberikan nilai berkisar 2,95 - 3,85 dengan kriteria biasa hingga suka. Hal ini menunjukan bahwa panelis menyukai warna dari seduhan teh herbal daun kenikir.

Tabel 8. Nilai rata-rata uji skoring warna seduhan teh herbal daun kenikir

\begin{tabular}{cccc}
\hline $\begin{array}{c}\text { Suhu } \\
\text { Pelayuan }\end{array}$ & Lama (menit) & Skoring & Hedonik \\
\hline \multirow{2}{*}{$\mathbf{7 0}^{\circ} \mathbf{C}$} & 1 & $2,25 \pm 0,44 \mathrm{a}$ & $2,95 \pm 0,47 \mathrm{a}$ \\
& 2 & $2,30 \pm 0,47 \mathrm{a}$ & $3,40 \pm 0,82 \mathrm{ab}$ \\
\multirow{2}{*}{$\mathbf{8 0}^{\circ} \mathbf{C}$} & 3 & $2,45 \pm 0,51 \mathrm{a}$ & $3,55 \pm 0,81 \mathrm{~b}$ \\
& 1 & $2,80 \pm 0,41 \mathrm{a}$ & $3,40 \pm 0,75 \mathrm{ab}$ \\
& 2 & $2,95 \pm 0,61 \mathrm{~b}$ & $3,55 \pm 0,83 \mathrm{~b}$ \\
$\mathbf{9 0}^{\circ} \mathbf{C}$ & 3 & $3,25 \pm 0,44 \mathrm{c}$ & $3,70 \pm 0,94 \mathrm{~b}$ \\
& 1 & $4,15 \pm 0,37 \mathrm{e}$ & $3,85 \pm 0,75 \mathrm{~b}$ \\
& 2 & $4,25 \pm 0,44 \mathrm{e}$ & $3,80 \pm 0,62 \mathrm{~b}$ \\
& 3 & $3,60 \pm 0,50 \mathrm{~d}$ & $3,65 \pm 0,89 \mathrm{~b}$ \\
\hline
\end{tabular}

Keterangan : Huruf yang sama pada kolom yang sama menunjukan perlakuan tidak berbeda nyata $(P>0,05)$. Kriteria nilai skoring : $5=$ Hijau kekuningan; $4=$ Kuning kehijauan; $3=$ Kuning; $2=$ Kuning kemerahan; $1=$ Merah kecoklatan.

Kriteria nilai hedonik $:(5=$ Sangat suka; $4=$ Suka; $3=$ Biasa $; 2=$ Tidak suka $; 1=$ Sangat tidak suka $)$.

\section{Rasa}

Hasil analisis uji skoring dan hedonik terhadap rasa seduhan teh herbal daun kenikir dapat dilihat pada Tabel 9. Hasil sidik ragam menunjukkan bahwa perlakuan suhu dan lama pelayuan berpengaruh nyata $(P>0,05)$ terhadap rasa seduhan teh herbal daun kenikir yang diuji secara skoring. Nilai rata-rata uji skrong rasa yang diberikan oleh panelis sebesar 2,05-3,00 dengan kriteria pahit hingga agak pahit. Rasa pahit dari seduhan teh herbal daun kenikir dihasilkan dari senyawa katekin yang terkandung di dalam daun kenikir Shui, et al. (2005). Menurut Ramlah (2017), katekin dapat memberi rasa pahit pada seduhan air teh. Hal ini juga sesuai dengan penelitian yang dilaporkan oleh Ulandari, et al. 
(2019) dimana semakin tinggi katekin yang terkandung di dalam daun teh, maka rasa pahit yang ditimbulkan juga semakin tinggi. Berdasarkan hasil sidik ragam perlakuan suhu dan lama pelayuan berpengaruh tidak nyata $(P>0,05)$ terhadap uji hedonik rasa seduhan teh herbal daun kenikir. Nilai rata-rata yang diberikan oleh panelis berkisar antara 3,0 - 3,4 dengan kriteria biasa. Hal ini menunjukan bahwa rasa yang dihasilkan oleh seduhan teh herbal daun kenikir masih dapat diterima oleh panelis.

Tabel 9. Nilai rata-rata uji skoring dan hedonik rasa, nilai rata-rata uji hedonik penerimaan keseluruhan seduhan teh herbal daun kenikir

\begin{tabular}{ccccc}
\hline $\begin{array}{c}\text { Suhu } \\
\text { Pelayuan }\end{array}$ & $\begin{array}{c}\text { Lama } \\
\text { (menit) }\end{array}$ & \multicolumn{2}{c}{ Rasa } & $\begin{array}{c}\text { Penerimaan } \\
\text { Keseluruhan }\end{array}$ \\
\cline { 2 - 5 } & & Skoring & Hedonik & Hedonik \\
\hline \multirow{2}{*}{$\mathbf{7 0}^{\circ} \mathbf{C}$} & 1 & $3,00 \pm 0,65 \mathrm{~b}$ & $3,40 \pm 0,66 \mathrm{a}$ & $3,40 \pm 0,82 \mathrm{a}$ \\
& 2 & $2,80 \pm 0,70 \mathrm{~b}$ & $3,30 \pm 0,80 \mathrm{a}$ & $3,40 \pm 0,82 \mathrm{a}$ \\
& 3 & $2,70 \pm 0,66 \mathrm{~b}$ & $3,15 \pm 0,81 \mathrm{a}$ & $3,10 \pm 0,79 \mathrm{a}$ \\
$\mathbf{8 0}^{\circ} \mathbf{C}$ & 1 & $2,45 \pm 0,76 \mathrm{ab}$ & $3,05 \pm 0,69 \mathrm{a}$ & $3,10 \pm 0,72 \mathrm{a}$ \\
& 2 & $2,55 \pm 0,83 \mathrm{ab}$ & $2,95 \pm 0,76 \mathrm{a}$ & $3,05 \pm 0,76 \mathrm{a}$ \\
& 3 & $2,05 \pm 0,89 \mathrm{a}$ & $2,90 \pm 0,91 \mathrm{a}$ & $2,90 \pm 0,85 \mathrm{a}$ \\
$\mathbf{9 0}^{\circ} \mathbf{C}$ & 1 & $2,80 \pm 0,95 \mathrm{~b}$ & $3,35 \pm 0,75 \mathrm{a}$ & $3,25 \pm 0,79 \mathrm{a}$ \\
& 2 & $2,60 \pm 0,94 \mathrm{~b}$ & $3,00 \pm 0,65 \mathrm{a}$ & $3,45 \pm 0,89 \mathrm{a}$ \\
& 3 & $2,65 \pm 0,49 \mathrm{~b}$ & $3,15 \pm 0,81 \mathrm{a}$ & $2,75 \pm 0,97 \mathrm{a}$ \\
\hline
\end{tabular}

Keterangan : Huruf yang sama pada kolom yang sama menunjukan perlakuan tidak berbeda nyata $(P>0,05)$. Kriteria Nilai skoring : 5 (Sangat tidak pahit); 4 (Tidak pahit); 3 (Agak pahit); 2 (Pahit); 1(Sangat pahit) Kriteria Nilai hedonik : 5 (Sangat suka); 4(Suka); 3(Biasa); 2 (Tidak suka) ; 1 (Sangat tidak suka)

\section{Penerimaan keseluruhan}

Penerimaan keseluruhan dilakukan untuk melihat tingkat kesukaan panelis secara keseluruhan dari segi aroma, warna dan rasa dari produk teh herbal daun kenikir. Berikut hasil analisis uji hedonik terhadap penerimaan keseluruhan seduhan teh herbal daun kenikir yang dapat dilihat pada Tabel 10. Hasil sidik ragam menunjukan bahwa perlakuan suhu dan lama pelayuan berpengaruh tidak nyata $(P>0,05)$ terhadap penerimaan keseluruhan seduhan teh herbal daun kenikir yang diuji secara hedonik. Nilai rata-rata uji hedonik terhadap penerimaan keseluruhan seduhan teh herbal daun kenikir berkisar antara 2,75 - 3,45 dengan kriteria biasa. Hal ini menunjukan bahwa panelis dapat menerima produk teh hijau daun kenikir dari segi warna, aroma dan rasa teh herbal daun kenikir. 


\section{KESIMPULAN DAN SARAN}

\section{Kesimpulan}

Berdasarkan hasil penelitian di atas, dapat disimpulkan sebagai berikut :

1. Interaksi suhu dan lama pelayuan pada proses pengolahan teh herbal daun kenikir (Cosmos caudatus Kunth.) berpengaruh sangat nyata terhadap kadar air, total fenol, total flavonoid, aktivitas antioksidan dan warna (uji skoring) dari teh herbal daun kenikir. Namun, masingmasing perlakuan suhu dan perlakuan lama pelayuan berpengaruh nyata terhadap kadar ekstrak dalam air dan total vitamin C.

2. Suhu pelayuan $90^{\circ} \mathrm{C}$ selama 2 menit menghasilkan bubuk teh herbal daun kenikir dengan komponen bioaktif tertinggi. Karakteristik bubuk teh herbal daun kenikir yang dihasilkan yaitu kadar air sebesar 6,76\% b/b, kadar ekstrak dalam air sebesar 32,89\%, total fenol sebesar 79,26 mg GAE/g bubuk teh, total flavonoid sebesar 161,01 mg QE/g bubuk teh, vitamin $\mathrm{C}$ sebesar $3,35 \mathrm{mg} / \mathrm{g}$ bubuk teh dan aktivitas antioksidan sebesar $74,29 \%$ dengan nilai $\mathrm{I}_{\mathrm{C} 50}$ yang terukur sebesar 24,409 ppm. Adapun karakteristik air seduhan teh yang dihasilkan yaitu aroma agak khas teh herbal daun kenikir dan disukai, warna seduhan teh kuning kehijauan disukai, rasa agak pahit dan biasa dan penerimaan keseluruhan biasa.

\section{Saran}

Adapun saran yang dapat diberikan yaitu perlu dilakukan yaitu proses pelayuan dalam pengolahan teh herbal daun kenikir sebaiknya dilakukan pada suhu $90^{\circ} \mathrm{C}$ selama 2 menit untuk memperoleh produk teh herbal daun kenikir dengan karakteristik terbaik.

\section{DAFTAR PUSTAKA}

Adri, D. dan W. Hersoelistyorini. 2013. Aktivitas antioksidan dan sifat organoleptik teh daun sirsak (Annona muricata Linn.) berdasarkan variasi lama pengeringan. Journal Pangan dan Gizi 04(7):1-12.

Almatsier, S. 2004. Prinsip Dasar Ilmu Gizi. Gramedia Pustaka Utama, Jakarta.

Anonim. 2014. Standar Nasional Indonesia (SNI) 4324:2014. Syarat Mutu Teh Hijau Celup. Dewan Standar Nasional Indonesia- DSN. Jakarta.

AOAC, 2005. Official Methods of Analysis. Association of Official Analytical Chemists. Benjamin Franklin Station, Washington.

Batari, R.. 2007. Identifikasi Senyawa Flavonoid pada Sayuran Indigenous Jawa Barat. Skripsi. Tidak dipublikasikan, Bogor: Institut Pertanian Bogor.

Bunawan, H., Baharum., S.N. Amin and N. M. Noor. 2014. Cosmos caudatus Kunth.: A Traditional Medicinal Herb, Global Journal of Pharmacology, 8 (3), 420-426

Chaturvedula, V. S. and I. Prakash 2011. The aroma, taste, color and bioactive constituents of tea. Journal of Medicinal Plants Research 5(11) : 2110-2124.

Fatanah, D.N, N. Abdullah, N. Hashim and A. A. Hamid. 2016. Antioxidant activity, colour ada mineral content, of herbal tea preparedfrom Cosmos caudatus leaves at different maturity stages.Malaysia Journal of Analytical Sciences. Vol 20 (3) :607 617

Felicia, N, I. W. R. Widarta dan N. L. Ariyusasrini. 2016. Pengaruh ketuaan daun dan metode pengolahan terhadap aktivitas antioksidan dan karakteristik sensoris teh herbal bubuk daun alpukat (Persea americana Mill.). Jurnal Ilmu dan Teknologi Pangan. Vol 5(2):85-94 
Garcia, C.A., G. Gavino., M. B. Mosqueda. P. Hevia and V. C. Gavino. 2007. Correlation of tocopherol, tokotrienol, $\gamma$-oryzanol and total polyphenol content in rice bran with different

Ghasemzadeh, A., V. Omidvar and H.Z.E. Jaafar. 2012. Polyphenolic content and their antioxidant activity in leaf extract of sweet potato (Ipomoea batatas). Journal of Medicinal Plant Research. Vol 6(15): 29712976

Gomes, K. A. dan A. A. Gomes. 1995. Prosedur Statistik Untuk Penelitian Pertanian. UI Press, Jakarta

Holman, J. P. 1995. Perpindahan Kalor. Penerjemah Jasjfi. E. Ir. M.Sc. Edisi Keenam. Erlangga. Jakarta.

Horžić, D., D. Komes, A. Belščak, K. K. Ganić, D. Iveković and D. Karlović. (2009). The composition of polyphenols and methylxanthines in teas and herbal infusions. Food Chemistry, 115(2): 441 448.

Josipovic, A., R. Sudar, A. Sudaric, V. Jurkovic, M.M. Kocar dan A. M. Kulundžic. 2016. Total phenolic and total flavonoid content variability of soybean genotypes in eastern Croatia. Croatatian Journal Food Science Technology 8 (2):60-65.

Karina, A. 2008. Pemanfaatan Jahe (Zingiber officinale Rosc.) Dan Teh Hijau (Camelia sinensis) Dalam Pembuatan Selai Rendah Kalori Dan Sumber Antioksidan. Skripsi. Fakultas Pertanian. Institut Pertanian, Bogor.

Mardiah, E. 2011. Mekanisme inhibisi enzim polifenol oksidase pada sari buah markisa dengan sistein dan asam askorbat. Jurnal. Vol 4(2): 32-37

Molyneux, P., 2004. The Use of The Stable Free Radical Diphenylpicryl-hydrazyl (DPPH) for Estimating Antioxidant Activity, Songklanakarin J. Sci. Technol. 26(2), 211-21

Neuma, H.J. 1972. Dehydrated Celery: Effect of Predrying Treatment and Rehydration Procedure are Reconstitution. J.Food.Sci.73:437-441.
Nurhayati., D. W. Marseno., F. M. C. S. Setyabudi., Supriyanto. 2018. Pengaruh steam blanching terhadap aktivitas polifenol oksidase, total polifenol dan aktivitas antioksidan biji kakao. Jurnal Aplikasi Teknologi Pangan 7(3): 95-103.

Patin, E. W., M. A. Zaini dan Y. Sulastri. 2018. Pengaruh Variasi Suhu Pengeringan Terhadap Sifat Fisiko Kimia Teh Daun Sambiloto (Andrographis paniculata). Jurnal Ilmu dan Teknologi Pangan. Vol 4(1) : 251-258.

Prabandari, I. M. 2015. Pengaruh Lama Penyimpanan dan Perebusan Daun Sirsak Segar (Annona muricata Linn) Terhadap Aktivitas Antioksidan Sari Daun Sirsak. Skripsi. Fakultas Teknologi Pertanian. Institut Pertanian, Bogor.

Queiroz, C., M. L. Lopes., Fialho, E and V. L. V. Mesquita. 2008. Polyphenol oxidase: characteristics and mechanisms of browning control. Food Review International 24: 361375 .

Rachmani, E. P. N. 2009. Penentuan mutu ekstrak etanolik daun kenikir (Cosmos caudatus Kunth.) dengan parameter flavonoid total dan minyak atsiri. Tidak dipublikasi. Ilmu Farmasi. Universitas Gadjah Mada, Yogyakarta.

Rahmawati, N., A. Fernando dan Wachyuni. 2013. Kandungan fenolik dan aktivitas antioksidan ekstrak daun gambir kering Uncaria Gambir (Hunter) ROXB). Jurnal Indonesia Chemia Acta. Vol 4(1):1-6..

Ramlah. 2017. Penentuan Suhu Dan Waktu Optimum Penyeduhan Daun Teh Hijau (Camellia Sintesis L.) P+2 Terhadap Kandungan Antioksidan Kafein, Tanin Dan Katekin. Skripsi. Tidak dipublikasikan. Fakultas Sains dan Teknologi UIN Alauddin, Makassar.

Ratnaningrum, S. P., Zainuri dan S. Saloko. 2018. Pengaruh suhu dan lama pelayuan terhadap mutu teh hijau daun kakao (Theobroma cacao L.). Fakultas Teknologi Pangan dan Agroindustri. Universitas Mataram, Mataram 
Saikia, S. and C. Mahanta. 2013. Effect of steaming, boiling and microwave cooking on the total phenolics, flavonoids and antioxidant properties of different vegetables of Assam, India. International Journal of Food and Nutritionl Sciences. Vol 2 : 47-53.

Shah and Modi.2015. Comparative study of DPPH, ABTS and FRAP assay for determination antioxidant activity. International Journal for Reasearch in Applied Scince and Engineering Technology (IJRATES) 3(4):636-641.

Shui, G., L Leong and P. W. Shih. 2005. Rapid screening and characterisation of antioxidants of Cosmos Caudatus using liquid chromatography coupled with mass spectrometry. Journal Chromatografi Bioanalitic Techonology Biomedical Life Science. Vol 827: 127-138.

Soekarto. 1990. Penilaian Organoleptik Untuk Industri Pangan dan Hasil Pertanian. Jakarta: Bhatara Aksara.

Suksmadji, B. 1987. Beberapa Sifat Pati Gaplek. Fakultas Pertanian Pasca Sarjana UGM, Yogyakarta.

Uckiah, A., D. Goburdhun and A. Ruggoo. 2009. Vitamin $\mathrm{C}$ content during processing and storage of pineapple. Nutrition \& Food Science. Vol 39(4): 3 98-412.
Ulandari, D. A.T., K. A. Nocianitri dan N. M. I. H. Arihantana. 2019. Pengaruh suhu pengeringan terhadap kandungan komponen bioaktif dan karakteristik sensoris teh white peony. Jurnal Ilmu dan Teknologi Pangan. Vol. 8(1): 36-47

Velioglu Y. S., G. Mazza., L. Gao and B. D. Oomah. 1998 Antioxidant activity and total phenolics in selected fruits, vegetables, and grain products. J Agri Food Chem. Vol 46: 4113-4117.

Waji, R.A dan A. Sugrani. 2009. Flavonoid (Quercetin). [Skripsi]. Makasar: Fakultas Matematika dan Ilmu Pengetahuan Alam. Universitas Hasanuddin.

Winarno, F. G. 2004. Kimia Pangan dan Gizi. PT. Gramedia, Jakarta

Yudana, I. G. A. 2004. Mengenal Ragam dan Manfaat Teh. http://www.indomedia.com/intisari/1998,teh .html. Diakses pada tanggal 13 Januari 2018

Yulianto, E.M, Senen dan D. Ariwibowo. 2006. Studi awal rekayasa proses produksi teh hijau berkatekin tinggi melalui teknologi steaming. Media komunikasi Rekayasa Proses dan Teknologi Tepat Guna. Vol 4(1):1-7 